\title{
PERAN SELF-ESTEEM DALAM MENCEGAH EMOTIONAL DISTRESS: LOCUS OF CONTROL SEBAGAI ANTECEDENT
}

\author{
Lukas Juliano $^{1}$ dan P. Tommy Y. S. Suyasa ${ }^{2}$ \\ ${ }^{1}$ Program Studi Sarjana Psikologi, Universitas Tarumanagara, Jakarta \\ Email: lukasjuliano.lj@gmail.com \\ ${ }^{2}$ Fakultas Psikologi, Universitas Tarumanagara, Jakarta \\ Email: tommys@fpsi.untar.ac.id
}

Masuk : 13-01-2020, revisi: 28-04-2020, diterima untuk diterbitkan : 30-04-2020

\begin{abstract}
Nowadays, there are several phenomenons of suicide in-between university students whom are doing their thesis in Indonesia. One of the sources of suicide is emotional distress. Emotional distress is an uncomfortable state which can cause several lose, usually marked by depression and/or anxiety symptoms. There exist a few anti-stress variables to help coping process toward emotional distress, two of which are self-esteem and locus of control. This experiment's goal is to figure out the state of the three variables on university students currently doing their thesis, while figuring out the relations of the anti-stress variables to emotional distress in the process of doing so. The participants in this experiment is 163 university students from X University currently doing their thesis, with age between 20-24 years old. From the data analysis, there are two conclusions. First, emotional distress is higher in university student doing thesis than common individual. Second, emotional distress can be predicted by self-esteem; furthermore, self-esteem is predicted by locus of control. The experiment is hoped to be able to provide insight in preventing emotional distress, specifically in university student struggling with their thesis.
\end{abstract}

Keywords: emotional distress, self-esteem, locus of control, university student, thesis

\begin{abstract}
ABSTRAK
Saat ini, terdapat beberapa fenomena bunuh diri di kalangan mahasiswa yang sedang mengerjakan skripsi di Indonesia. Salah satu penyebab naiknya tingkat bunuh diri adalah emotional distress. Emotional distress adalah keadaan tidak menyenangkan yang dapat mengakibatkan berbagai kerugian, umumnya ditandai dengan gejala depresi dan/atau kecemasan. Terdapat beberapa variabel anti-stres yang terbukti mampu mengurangi emotional distress, dua di antaranya adalah self-esteem dan locus of control. Penelitian ini bertujuan memeroleh gambaran ketiga variabel ini pada mahasiswa yang sedang mengerjakan skripsi, sekaligus mencari peran kedua variabel antistres tersebut terhadap emotional distress pada partisipan penelitian. Partisipan penelitian meliputi 163 orang mahasiswa yang sedang menyusun skripsi, dengan rentang usia 20 hingga 24 tahun. Berdasarkan analisis data, diperoleh dua kesimpulan. Pertama, tingkat emotional distress pada mahasiswa yang sedang mengerjakan skripsi, lebih tinggi dibandingkan individu pada umumnya. Kedua, emotional distress dapat diprediksi oleh self-esteem; dan lebih lanjut self-esteem diprediksi oleh locus of control. Penelitian ini bermanfaat memberikan insight dalam pencegahan emotional distress, khususnya pada mahasiswa yang sedang mengerjakan skripsi.
\end{abstract}

Kata Kunci: emotional distress, self-esteem, locus of control, mahasiswa, skripsi

\section{PENDAHULUAN}

\section{Latar Belakang}

Skripsi adalah karangan ilmiah yang harus diselesaikan seorang mahasiswa sebagai syarat kelulusan perguruan tinggi (KBBI, 2019). Dalam proses pengerjaan skripsi, mahasiswa kerap mengalami berbagai kendala. Beberapa kendala paling umum adalah perbedaan pendapat saat berdiskusi dengan dosen pembimbing, kurangnya pengalaman dalam menyusun karya tulis ilmiah, dan pola pikir yang menganggap skripsi adalah suatu beban (Matin \& Khan, 2017). Kendala-kendala tersebut akan mengakibatkan mahasiswa mengalami emotional distress apabila tidak dibarengi oleh kemampuan manajemen waktu yang mumpuni. Hal ini ditandai dengan perasaan frustrasi, melakukan isolasi diri, dan timbulnya kecemasan. 
Ketiga hal tersebut menunjukkan ciri-ciri emotional distress yang dialami dalam pengerjaan skripsi. Emotional distress menurut Hankin, Roberts dan Gotlib (1997) adalah gabungan gejala depresi dan kecemasan yang muncul pada suatu individu. Hal ini ditandai dengan rentannya individu pada emosi yang kurang menyenangkan seperti ketidakpuasan diri, kesedihan, dan perasaan kecewa. Individu yang mengalami emotional distress juga mudah merasa cemas, khawatir, dan takut.

Pada kalangan pelajar dan mahasiswa, emotional distress dapat berdampak buruk. Mahasiswa dan mahasiswi yang memiliki emotional distress yang tinggi cenderung lebih rentan terhadap perilaku bunuh diri (suicide behavior) dibandingkan dengan mereka yang tidak memiliki emotional distress sama sekali. Menurut hasil perhitungan penelitian, perilaku bunuh diri hadir pada $40.8 \%$ partisipan penelitian yang memiliki gejala depresi menengah hingga tinggi, dan hanya muncul pada $4.1 \%$ partisipan penelitian yang tidak memiliki gejala depresi (Tang, Byrne \& Qin, 2018).

Menurut hasil autopsi psikologi dari individu yang melakukan bunuh diri, terdapat tiga faktor yang berkorelasi dengan pemikiran dan tindakan bunuh diri, yaitu: depresi, kecemasan, dan stres. Depresi adalah faktor psikologis yang berperan penting dalam memprediksi tindakan bunuh diri. Banyak autopsi psikologi menunjukkan beberapa individu yang memikirkan, mencoba, hingga melakukan bunuh diri mengalami depresi (Phillips, Li \& Zhang, 2002). Selain depresi, kecemasan juga salah satu faktor yang berkorelasi dengan pemikiran dan tindakan bunuh diri. Dalam sebuah studi meta-analisis, Malik et al. (2014) meneliti mengenai hubungan kecemasan dan pemikiran bunuh diri. Hasilnya, mereka menyimpulkan bahwa penderita kecemasan cenderung lebih sering memikirkan, melakukan percobaan, hingga benar-benar melakukan bunuh diri dibandingkan mereka yang tidak mengalami kecemasan.

Untuk mencegah peningkatan perilaku bunuh diri, partisipan yang mengalami gejala emotional distress harus diidentifikasi dan diberikan penanganan secepatnya sebelum menjadi semakin parah. Pencegahan tersebut sulit untuk dilakukan karena emotional distress sulit untuk dideteksi pada masa remaja. Hal ini disebabkan karena masalah yang dialami oleh mahasiswa kerap dilihat sebagai hal yang normal (Mustaffa et al., 2013).

Emotional distress dapat diterjemahkan sebagai ketidaknyamanan atau stres emosional. Hankin, Kassel, dan Abela (2005) menyatakan bahwa emotional distress adalah keadaan emosional suatu individu yang ditandai dengan gejala-gejala gangguan depresi dan/atau kecemasan.

Tice, Bratslavsky, dan Baumeister (2001) berpendapat bahwa emotional distress adalah suatu keadaan (state) di mana individu merasa buruk dan tidak stabil sehingga mereka akan mencoba untuk melakukan apapun untuk merasa lebih baik. Hal ini mengakibatkan individu untuk beralih dari tujuan jangka panjang, dan dapat disebut juga sebagai self-defeating behavior.

Baumeister (1997) menyatakan bahwa emotional distress adalah keadaan emosional di mana terjadi penurunan self-esteem pada individu, ditandai dengan timbulnya gejala gangguan depresi maupun kecemasan. Emotional distress muncul saat pandangan seseorang terhadap dirinya terancam.

Dari beberapa pernyataan di atas, dapat disimpulkan bahwa emotional distress adalah suatu keadaan di mana individu merasakan emosi-emosi negatif. Emotional distress memiliki dua dimensi umum yaitu kecemasan dan depresi, dan berhubungan dengan diri individu sendiri (self). 
Emotional distress dapat diprediksi oleh usia, locus of control, dan self-esteem (Jiménez, Montorio, \& Izal, 2017). Hasil penelitian Jimenez et al. (2017) menunjukkan bahwa external locus of control berkorelasi secara negatif terhadap self-esteem, berkebalikan dengan internal locus of control yang berkorelasi secara positif. Self-esteem berperan sebagai variabel penghubung antara external locus of control dengan emotional distress dalam penelitian ini. Selfesteem berkorelasi negatif dengan emotional distress.

Dalam penelitian Jiménez et al. (2017), terdapat tiga hal yang belum terjelaskan terkait emotional distress. Pertama, latar dari penelitian ini adalah di Spanyol, yang memiliki budaya berbeda dengan negara Asia, khususnya Indonesia sehingga pandangan emotional distress dapat berbeda. Kedua, Jimenez et al. (2017) tidak melakukan kontrol usia pada penelitian mereka, partisipan memiliki usia yang bervariasi dari 18-87 tahun, sehingga bisa saja hasil penelitian berubah bila partisipan memiliki rentang usia homogen. Terakhir, tidak ada masalah spesifik yang dibahas dalam penelitian Jiménez et al. (2017). Skor emotional distress pada kalangan mahasiswa yang sedang mengerjakan skripsi bisa saja berbeda dengan individu lain. Argumen terhadap ketiga hal yang belum terjelaskan tersebut di atas, penulis paparkan pada beberapa alinea berikut.

Pertama, perbedaan budaya mempengaruhi pandangan individu terhadap depresi. Etnis Tionghoa menganggap depresi sebagai kelemahan neurologis. Hal tersebut lebih bisa diterima masyarakat dibandingkan gangguan mental yang dipandang sebagai sesuatu yang menyimpang secara sosial dan moral (Parker, Cheah, \& Roy, 2001). Di benua Asia bagian selatan, depresi dianggap sebagai reaksi emosional individu terhadap situasi yang tengah dihadapi. Meski begitu, penanganan medis dirasa tidak perlu untuk depresi. Masyarakat percaya bahwa "penanganan" terbaik adalah dengan menyelesaikan, atau mengabaikan masalah dalam situasi tersebut (Karasz, 2005) khususnya di negara Arab di mana depresi tidak dianggap sebagai gangguan psikologis melainkan kurangnya "iman" dari pasien. Alhasil, solusi yang ditawarkan pada individu yang mengalami depresi adalah mendekatkan diri kepada Tuhan dengan membaca kitab suci, berdoa, dan meminta saran pada sosok yang religius (Sulaiman, Bhugra \& de Silva, 2004).

Di belahan dunia bagian barat seperti Eropa dan Amerika, etnis berkulit hitam memiliki kecenderungan memilih konseling spiritual sebagai penanganan depresi, sedangkan etnis berkulit putih lebih condong mengandalkan obat-obatan (Givens et al., 2007). Pada negara-negara Barat, depresi juga sudah diakui sebagai gangguan psikologi secara umum oleh pemerintah dan juga masyarakat (Karasz, 2005).

Kedua, banyak penelitian yang mengaitkan self-esteem dengan well-being (Padhy, Rana, \& Mishra, 2011; Neff, 2011). Well-being manusia selalu berubah-ubah tergantung pada usia mereka, mengikuti grafik berbentuk huruf U (Blanchflower \& Oswald, 2008; Steptoe, Deaton, \& Stone, 2015). Self-esteem mempengaruhi emotional distress. Dengan kata lain, emotional distress pada individu rentang usia tertentu akan berbeda dengan rentang usia lainnya. Jimenez et al. (2017) tidak membagi rentang usia, sehingga hasil yang didapatkannya akan menjadi kurang spesifik.

Ketiga, emotional distress dapat disebabkan oleh banyak hal. Dalam penelitian Jimenez et al. (2017), tidak dijelaskan fenomena khusus yang menjadi acuan emotional distress, sedangkan terdapat fenomena mengenai mahasiswa skripsi yang mengalami emotional distress. Berdasarkan ketiga argumen tersebut, peneliti menyusun penelitian ini untuk menerapkan penelitian Jimenez et al. (2017) pada fenomena mahasiswa yang sedang mengerjakan skripsi, 
berlatar belakang budaya Indonesia dengan usia lebih spesifik. Diharapkan dengan hal ini, hasil yang didapatkan akan lebih relevan dengan fenomena yang ada.

\section{Peran Self-Esteem dalam Memprediksi Emotional Distress}

Self-esteem atau harga diri adalah pemikiran dan penilaian seorang manusia pada dirinya sendiri sebagai sebuah obyek (Rosenberg, 1979). Self-esteem dapat bersifat positif maupun negatif, serta mempengaruhi perilaku seseorang terhadap dirinya sendiri.

Menurut Rosenberg (1965), individu dengan self-esteem yang tinggi berarti ia menganggap dirinya sendiri layak dan menghormati dirinya sendiri. Namun, ia tidak memandang dirinya sendiri dengan kekaguman mendalam, atau mengharapkan orang lain kagum padanya. Individu dengan self-esteem tinggi juga tidak harus selalu memandang dirinya superior dibandingkan orang lain.

Self-esteem adalah aspek yang sangat penting dalam kehidupan seorang individu. Telah banyak teori psikologi yang berpendapat bahwa setiap orang termotivasi untuk meningkatkan dan mempertahankan self-esteem yang tinggi, tanpa memedulikan nilai fungsionalnya (Pyszczynski, Greenberg, Solomon, Arndt, \& Schimel, 2004). Namun, terdapat juga beberapa pendekatan yang mencari tahu alasan self-esteem begitu penting bagi manusia, beberapa di antaranya adalah teori sosiometer (Leary \& Baumeister, 2000; Leary, Tambor, Terdal, \& Downs, 1995) yang menyatakan manusia memiliki kebutuhan dasar akan kebersamaan (belongingness) dan akan melakukan segala cara untuk dipandang berharga di kelompoknya, dan teori manajemen teror (Greenberg, Pyszczynski, \& Solomon, 1986; Pyszczynski et al., 2004) dimana setiap manusia menghadapi konflik psikologis dasar berupa kecemasan pada kematian, dan meningkatkan selfesteem guna mengurangi kecemasan tersebut. Kedua teori ini juga menyatakan dampak buruk jika individu gagal untuk meningkatkan self-esteem mereka. Dalam kasus teori sosiometer, individu yang tidak mendapatkan kebutuhan dasarnya akan kebersamaan dapat mengalami kesepian dan kekurangan dukungan sosial, kedua hal ini beresiko mengakibatkan depresi (Nolan, Flynn, \& Garber, 2003; Stice, Ragan, \& Randall, 2004). Sedangkan dalam teori manajemen teror, individu akan mendapatkan tekanan sosial (social pressure) yang membuatnya semakin rentan terhadap emosi-emosi negatif. Individu dengan self-esteem yang rendah memiliki kecenderungan untuk lebih terpengaruh oleh emosi negatif ketika diingatkan akan kematian (Routledge et al., 2010). Melalui penjelasan di atas, dapat dirumuskan hipotesis pertama bahwa semakin positif self-esteem semakin rendah emotional distress.

H1: Self-esteem berhubungan negatif dengan emotional distress.

\section{Peran Locus of Control dalam Memprediksi Self-Esteem}

Locus of control adalah derajat kepercayaan individu mengenai kendali mereka pada hal-hal yang terjadi dalam kehidupan individu tersebut. Konsep locus of control pertama kali diperkenalkan oleh Rotter (1954). Locus adalah bentuk jamak dari loci, yang berarti "lokasi" dalam bahasa latin. Secara harfiah, locus of control berarti lokasi kontrol. Rotter membagi derajat kepercayaan tersebut menjadi dua, individu yang yakin bahwa kehidupannya dikendalikan oleh dirinya sendiri memiliki internal locus of control yang kuat, sedangkan individu yang merasa hidupnya dikendalikan oleh faktor luar (orang lain yang lebih berkuasa, kesempatan, peluang, keberuntungan, takdir, dll) memiliki external locus control yang kuat. (Rotter, 1966). 
Locus of control memegang pengaruh besar terhadap cara individu memandang segala aspek dirinya, dan juga reaksinya atas lingkungan di sekitarnya (Gershaw, 1999). Slavin (1997) menyatakan locus of control adalah keyakinan individu mengenai hubungan antara perilaku dan konsekuensi yang diperolehnya. Hal ini merupakan bagian dari karakteristik kepribadian, dan terbagi menjadi dua. Karakteristik yang menganggap konsekuensi dari kesuksesan maupun kegagalan berasal dari diri sendiri bersifat internal, sedangkan yang menganggap konsekuensi tindakan berasal dari faktor luar bersifat external.

Konsep locus of control bukanlah konsep tipologis, yang menempatkan individu menjadi suatu golongan tipe tertentu (internal atau external), melainkan suatu garis kontinum dimana letak posisi individu berada di sepanjang garis kontinum tersebut. Garis kontinum yang dimaksud di sini berkisar antara internal locus of control dan external locus of control (Miner, 1992). Menurut Rotter (dalam Miner, 1992), locus of control yang dimiliki individu bisa sangat condong ke arah internal maupun external. Tapi umumnya, locus of control individu terletak di antara keduanya.

Locus of control termasuk dalam salah satu variabel anti-stres, dan berhubungan dengan wellbeing dengan dimediasi oleh faktor lain. Bila seseorang memandang dirinya memiliki kendali atas hidupnya, well-being akan meningkat, sebaliknya, tanpa pandangan positif tersebut, wellbeing akan menurun (Lang \& Heckhausen, 2001). Well-being yang positif dapat diasosiasikan dengan keinginan untuk meningkatkan kualitas diri, dan juga self-concept yang positif (Cummins \& Nistico, 2002; Lang \& Heckhausen, 2001). Penemuan ini tidak hanya menunjukkan seberapa penting kepercayaan kontrol individu penting untuk mempertahankan well-being, namun juga mempermudah penyelesaian konflik dan meningkatkan kepercayaan diri serta self-esteem. Dalam model penelitian Jimenez et al. (2017), self-esteem menjadi variabel penghubung kedua jenis locus of control terhadap emotional distress. Hal ini menimbulkan hipotesis kedua dalam penelitian ini.

$\mathrm{H} 2 \mathrm{a}$ : Internal locus of control berhubungan positif dengan self-esteem

$\mathrm{H} 2 \mathrm{~b}$ : External locus of control berhubungan negatif dengan self-esteem

\section{METODE PENELITIAN}

\section{Partisipan Penelitian}

Partisipan penelitian berjumlah 163 orang mahasiswa Universitas X yang sedang menjalani proses pengerjaan skripsi, 70 di antaranya berjenis kelamin laki-laki, dan 93 sisanya berjenis kelamin perempuan. Partisipan adalah mahasiswa semester 7 hingga 11, dan berada dalam rentang usia 20 hingga 24 tahun. Partisipan penelitian berasal dari 7 fakultas yang berbeda, yakni: ekonomi, psikologi, teknik, desain, kedokteran, hukum, dan komunikasi.

\footnotetext{
Alat Ukur

Penelitian ini menggunakan 3 alat ukur. Variabel emotional distress terbagi menjadi dua dimensi, yakni anxiety dan depression. Untuk mengukur variabel emotional distress, digunakan alat ukur Goldberg Anxiety and Depression Scale (Goldberg, Bridges, Duncan-Jones, \& Grayson, 1998) atau GADS. Alat ukur ini terdiri dari 18 butir pertanyaan. GADS menggunakan skala Likert (0-3) yang memiliki empat pilihan, dua di antaranya (0-1) berarti TIDAK dan (2-3) berarti IYA. Semakin dekat pilihan partisipan ke angka 0 , semakin mengindikasikan bahwa individu semakin tidak setuju pada pernyataan tersebut. Semakin dekat ke angka 3, semakin individu setuju terhadap pernyataan tersebut. GADS memiliki delapan belas butir untuk mengukur gejala kecemasan dan depresi. Sembilan di antaranya adalah butir kecemasan, dan sembilan sisanya adalah butir depresi. Contoh dari butir kecemasan adalah, "Apakah anda mudah
} 
merasa terganggu?", dan contoh butir depresi adalah, "Apakah anda kehilangan ketertarikan/minat?". Reliabilitas dimensi anxiety adalah 0,748 dan reliabilitas dimensi depression 0,833 .

Untuk mengukur variabel self-esteem, alat ukur yang digunakan adalah Rosenberg Self-Esteem Scale (Rosenberg, 1965) atau RSES. Alat ukur terdiri dari 10 butir pernyataan berbentuk skala Likert. Respon yang dapat diberikan memiliki rentang angka dari (1) hingga (4). Angka (1) mengindikasikan bahwa individu sangat tidak setuju (STS) dengan pernyataan tersebut, angka (2), (3), dan (4) secara beruntun mengindikasikan individu tidak setuju (TS), setuju (S), dan sangat setuju (SS) terhadap pernyataan tersebut. RSES terdiri dari sepuluh buah butir. Lima di antaranya adalah butir positif, dan sisanya adalah butir negatif. Contoh dari butir positif adalah, "Saya tergolong orang yang percaya diri". Sedangkan contoh dari butir negatif adalah, "Terkadang saya benar-benar merasa tidak berguna". Reliabilitas dimensi self-esteem adalah 0,846 .

Variabel locus of control dalam penelitian ini diukur menggunakan Levenson Multidimensional Locus of Control Scale (Levenson, 1973). Alat ukur ini terdiri dari 24 butir dalam bentuk skala Likert (1-6). Respon yang diberikan mulai dari sangat tidak setuju (STS), tidak setuju (TS), agak tidak setuju (ATS), agak setuju (AS), setuju (S), dan sangat setuju (SS). Skala ini mengukur dua jenis dimensi dari locus of control, yakni internal (internality) dan eksternal (powerful others dan chance). Contoh butir dari internal locus of control adalah, "Hidup saya bergantung sepenuhnya pada tindakan dan perbuatan saya". Contoh butir dari external locus of control adalah, "Apa yang saya ingin lakukan terkadang tidak terwujud karena nasib buruk" dan, "Orang-orang di atas saya sangat menentukan kesuksesan rencana saya". Reliabilitas dimensi external locus of control adalah 0,884 dan reliabilitas dimensi internal locus of control adalah 0,849.

\section{HASIL DAN PEMBAHASAN}

Berdasarkan hasil analisis, nilai rata-rata dimensi depression adalah 1,462 $(S D=0,557)$. Nilai rata-rata skor depression mahasiswa skripsi ini sedikit lebih rendah dibandingkan dengan nilai titik tengah alat ukur yaitu 1,5. Artinya, para mahasiswa tidak merasa bahwa mereka mengalami gangguan depresi dalam proses pengerjaan skripsi.

Nilai rata-rata dimensi anxiety adalah 1,29 $(S D=0,636)$, yang masih sedikit lebih rendah dibandingkan dengan nilai titik tengah alat ukur yaitu 1,5. Artinya, para mahasiswa tidak merasa bahwa mereka mengalami gangguan kecemasan dalam proses pengerjaan skripsi.

Nilai rata-rata variabel self-esteem adalah 1,78 $(S D=0,524)$, angka ini lebih tinggi dibandingkan dengan nilai tengah alat ukur yaitu 1,5. Artinya, mahasiswa merasa bahwa diri mereka layak dan memiliki self-image yang cukup baik saat proses pengerjaan skripsi.

Nilai rata-rata dimensi external locus of control adalah 3,60 $(S D=0,712)$, angka ini sedikit lebih tinggi dibandingkan dengan nilai tengah alat ukur, yaitu 3,5. Artinya, para mahasiswa sedikit merasa bahwa nilai skripsi mereka ditentukan oleh faktor eksternal di luar kendali mereka seperti dosen pembimbing, administrasi, keberuntungan, dan lain-lain.

Nilai rata-rata dimensi internal locus of control adalah 4,42 $(S D=0,759)$, angka ini lebih tinggi dibandingkan dengan nilai tengah alat ukur, yaitu 3,5. Artinya, para mahasiswa merasa bahwa nilai skripsi mereka ditentukan oleh kerja keras mereka sendiri. Hasil lebih jelas diuraikan pada Tabel 1 dan Tabel 2. 
Tabel 1. Statistik Deskriptif Tiap Variabel

\begin{tabular}{cccccc}
\hline & $\mathbf{N}$ & Min & Max & Mean & SD \\
\hline Anxiety & 163 & 0 & 3 & 1,29 & 0,636 \\
Depression & 163 & 0 & 3 & 1,462 & 0,557 \\
Self-Esteem & 163 & 0 & 3 & 1,78 & 0,524 \\
Internal LOC & 163 & 1 & 6 & 4,42 & 0,759 \\
External LOC & 163 & 1 & 6 & 3,60 & 0,712 \\
\hline
\end{tabular}

Tabel 2. Korelasi Antar Variabel

\begin{tabular}{lcccccc}
\hline Variabel & $\mathbf{1}$ & $\mathbf{2}$ & $\mathbf{3}$ & $\mathbf{4}$ & $\mathbf{5}$ & $\mathbf{6}$ \\
\hline 1. ED & 1 & $0,915^{* *}$ & $0,935^{* *}$ & $\mathbf{- 0 , 5 3 0 * *}$ & $\mathbf{- 0 , 3 7 0 * *}$ & $\mathbf{0 , 4 3 7 * *}$ \\
2. ANX & $0,915^{* *}$ & 1 & $0,729^{* *}$ & $-0,489^{* *}$ & $-0,394^{* *}$ & $0,367 * *$ \\
3. DEP & $0,935^{* *}$ & $0,729^{* *}$ & 1 & $-0,510^{* *}$ & $-0,316^{* *}$ & $0,428^{* *}$ \\
4. SE & $-0,530^{* *}$ & $-0,489^{* *}$ & $-0,510^{* *}$ & 1 & $\mathbf{0 , 5 4 7 * *}$ & $\mathbf{- 0 , 5 2 3 * *}$ \\
5. INT & $\mathbf{- 0 , 3 7 0 * *}$ & $-0,394^{* *}$ & $-0,316^{* *}$ & $\mathbf{0 , 5 4 7 * *}$ & 1 & $-0,381^{* *}$ \\
6. EXT & $\mathbf{0 , 4 3 7 * *}$ & $0,367^{* *}$ & $0,428^{* *}$ & $\mathbf{- 0 , 5 2 3 * *}$ & $-0,381^{* *}$ & 1 \\
\hline
\end{tabular}

Catatan. $* p<0,05 . * * p<0,01$

Ket: ED: Emotional Distress; ANX: Anxiety; DEP: Depression ; SE: Self-Esteem; INT: Internal Locus of Control; EXT : External Locus of Control

Hasil yang diperoleh menunjukkan bahwa terdapat peran locus of control dan self-esteem terhadap emotional distress pada mahasiswa yang sedang mengerjakan skripsi. Self-esteem dan internal locus of control yang tinggi berperan untuk mengurangi emotional distress yang dialami oleh mahasiswa, sedangkan external locus of control yang tinggi berpotensi meningkatkan resiko mengalami emotional distress. Kedua, dimensi locus of control juga berperan terhadap selfesteem. Mahasiswa dengan internal locus of control yang tinggi cenderung juga memiliki selfesteem yang tinggi dalam proses mengerjakan skripsi. Sebaliknya, individu dengan external locus of control yang tinggi cenderung memiliki self-esteem yang rendah.

Hasil ini sesuai dengan temuan pada penemuan sebelumnya oleh Jimenez et al. (2017). Namun, setelah dilakukan konversi skor, ditemukan bahwa skor emotional distress pada mahasiswa dengan rentang usia dewasa muda lebih tinggi dibandingkan dengan partisipan penelitian Jimenez et al. (2017). Sebaliknya, skor self-esteem juga lebih rendah. Tidak ada perbedaan besar terhadap skor internal dan external locus of control. Artinya, meski tergolong cukup aman, kadar emotional distress pada partisipan penelitian ini tetap lebih tinggi dibandingkan penelitian terdahulu, selengkapnya pada.

Peneliti memperkirakan hasil ini terjadi karena individu dengan rentang usia dewasa muda lebih rentan terhadap emotional distress, ditambah lagi dengan skripsi sebagai sumber stres. Hasil ini sesuai dengan teori well-being (Blanchflower \& Oswald, 2008; Steptoe, Deaton, \& Stone, 2015), yang menyatakan bahwa grafik well-being berada di posisi rendah saat individu menginjak usia remaja-dewasa awal. 


\section{KESIMPULAN DAN SARAN}

Dari hasil penelitian dan pembahasan, dapat diketahui gambaran emotional distress, self-esteem dan locus of control pada mahasiswa yang sedang mengerjakan skripsi. Skor rata-rata dari tiap variabel mengindikasikan bahwa mahasiswa yang sedang mengerjakan skripsi cenderung memiliki emotional distress yang sedikit lebih rendah, serta self-esteem yang masih cukup tinggi, locus of control partisipan penelitian juga condong pada internal locus of control dibandingkan external locus of control. Melalui uji korelasi diketahui bahwa self-esteem berperan terhadap emotional distress. Self-esteem yang masih cukup tinggi pada mahasiswa berperan dalam menurunkan emotional distress yang mereka alami selama proses mengerjakan skripsi. Berdasarkan uji korelasi ditemukan bahwa internal dan external locus of control berperan terhadap self-esteem mahasiswa. Angka internal locus of control yang lebih tinggi berperan dalam meningkatkan self-esteem mereka, sedangkan angka external locus of control yang dapat mengurangi self-esteem tidak setinggi internal locus of control.

Peneliti menyadari bahwa penelitian ini masih memiliki banyak keterbatasan-keterbatasan. Salah satunya adalah, penelitian ini belum menjelaskan mengapa external locus of control tidak dapat berkorelasi langsung dengan emotional distress menurut model yang digunakan Jimenez et al. Keterbatasan kedua adalah, penelitian ini belum menguji secara langsung hubungan antara locus of control dan emotional distress. Untuk peneliti selanjutnya, peneliti menyarankan untuk mencari teori pendukung hubungan langsung locus of control dan emotional distress. Keterbatasan penelitian yang lain meliputi variabel lain yang belum diuji. Peneliti selanjutnya dapat memasukkan variabel usia dan optimisme bila mengangkat tema yang serupa, juga variabel spiritual karena budaya di negara Indonesia. Bila peneliti selanjutnya mengangkat tema mahasiswa yang sedang mengerjakan skripsi, disarankan untuk memasukkan variabel sudah berapa lama partisipan mengerjakan skripsi. Peneliti selanjutnya juga diharapkan mencari sumber literatur untuk meningkatkan self-esteem pada mahasiswa yang sedang mengerjakan skripsi. Melalui penelitian yang akan datang tersebut, diharapkan akan muncul solusi dan saran yang lebih baik untuk mengurangi munculnya emotional distress dan akibat negatifnya pada mahasiswa yang sedang mengerjakan skripsi. Selain variabel dan partisipan lain, peneliti juga menyarankan untuk mencari alat ukur variabel locus of control yang lebih singkat, namun tetap memiliki properti psikometri yang baik.

\section{Ucapan Terima Kasih (Acknowledgement)}

Peneliti mengucapkan terima kasih kepada berbagai pihak. Secara khusus kepada civitas akademika Universitas X, dan para mahasiswa yang terlibat secara sukarela dalam penelitian ini.

\section{REFERENSI}

Blanchflower, D. G., \& Oswald, A. J. (2008). Is well-being U-shaped over the life cycle?. Social Science \& Medicine, 66, 1733-1749.

Cummins, R. A., \& Nistico, H. (2002). Maintaining life satisfaction: The role of positive cognitive bias. Journal of Happiness Studies, 3(1), 37-69.

Givens, J. L., Houston, T. K., Van Voorhees, B. W., Ford, D. E., \& Cooper, L. A. (2007). Ethnicity and preferences for depression treatment. General Hospital Psychiatry, 29(3), 182-191.

Goldberg, D., Bridges, K., Duncan-Jones, P., \& Grayson, D. (1988). Detecting anxiety and depression in general medical settings. British Medical Journal, 297, 897-899.

Greenberg, J., Pyszczynski, T., \& Solomon, S. (1986). The causes and consequences of a need for self-esteem: A terror management theory. Dalam R. F. Baumeister (Ed.), Public self and private self (pp. 189-212). New York: Springer-Verlag. 
Hankin, B. L., Roberts, J., \& Gotlib, I. H. (1997). Elevated self-standards and emotional distress during adolescence: Emotional specificity and gender differences. Cognitive Therapy and Research, 21(6), 663-679.

Hankin, B. L., Kassel, J. D., \& Abela, J. R. Z. (2005). Adult attachment dimensions and specificity of emotional distress symptoms: Prospective investigations of cognitive risk and interpersonal stress generation as mediating mechanisms. Personality and Social Psychology Bulletin, 31(1), 136-151.

Jiménez, M. G., Montorio I., \& Izal M. (2017). The association of age, sense of control, optimism, and self-esteem with emotional distress. Developmental Psychology, 53(7), 1398-1403.

Kamus Besar Bahasa Indonesia (2019). Arti kata mahasiswa. Diakses dari: https://kbbi.web.id/cemas

Karasz, A. (2005). Cultural differences in conceptual models of depression. Social Science \& Medicine, 60, 1625-1635.

Lang, F. R., \& Heckhausen, J. (2001). Perceived control over development and subjective wellbeing: Differential benefits across adulthood. Journal of Personality and Social Psychology, 81(3), 509-523.

Leary, M. R., \& Baumeister, R. F. (2000). The nature and function of self-esteem: Sociometer theory. Advances in Experimental Social Psychology, 32, 1-62.

Leary, M. R., Tambor, E. S., Terdal, S. K., \& Downs, D. L. (1995). Self-esteem as an interpersonal monitor: The sociometer hypothesis. Journal of Personality and Social Psychology, 68(3), 518-530.

Levenson, H. (1973). Multidimensional locus of control in psychiatric patients. Journal of Consulting and Clinical Psychology, 41, 397-404.

Malik, S., et al. (2014). The association between sleep disturbances and suicidal behaviors in patients with psychiatric diagnoses: A systematic review and meta-analysis. Systematic Reviews Journal, 3(18).

Matin, M. A., \& Khan, M. A. W. (2017). Common problems faced by postgraduate students during their thesis works in Bangladesh. Bangladesh Journal of Medical Education, 8(1), 22-27.

Mustaffa, S., Aziz, R., Mahmood, M. N., \& Shuib, S. (2013). Depression and suicidal ideation among university students. Procedia - Social and Behavioral Sciences, 116, 4205-4208.

Neff, K. D. (2011). Self-Compassion, self-esteem, and well-being. Social and Personality Psychology Compass, 5(1), 1-12.

Nolan, S. A., Flynn, C., \& Garber, J. (2003). Prospective relations between rejection and depression in young adolescents. Journal of Personality and Social Psychology, 85(4), 745-755.

Padhy, M., Rana, S., \& Mishra, M. (2011). Self esteem and subjective wellbeing: Correlates of academic achievement of students. The International Journal's, 1(7), 148-156

Parker, G., Cheah, Y. C., \& Roy, K. (2001). Do the Chinese somatize depression? A crosscultural study. Social Psychiatry and Psychiatric Epidemiology: The International Journal for Research in Social and Genetic Epidemiology and Mental Health Services, 36(6), 287-293.

Phillips, M. R., Li, X., \& Zhang, Y. (2002). Suicide rates in China, 1995-99. Lancet, 359, 835840.

Pyszczynski, T., Greenberg, J., Solomon, S., Arndt, J., \& Schimel, J. (2004). Why do people need self-esteem? A theoretical and empirical review. Psychological Bulletin, 130(3), 435-468. 
Rosenberg, M. (1965). Society and the adolescent self-image. Princeton, NJ: Princeton University Press.

Routledge, C., Ostafin, B., Juhl, J., Sedikides, C., Cathey, C., \& Liao, J. (2010). Adjusting to death: The effects of mortality salience and self-esteem on psychological well-being, growth motivation, and maladaptive behavior. Journal of Personality and Social Psychology, 99(6), 897-916.

Steptoe, A., Deaton, A., \& Stone, A. A. (2015). Subjective wellbeing, health, and ageing. The Lancet, 385, 640-648.

Stice, E., Ragan, J., \& Randall, P. (2004). Prospective relations between social support and depression: Differential direction of effects for parent and peer support?. Journal of Abnormal Psychology, 113(1), 155-159.

Sulaiman, S. O. Y., Bhugra, D., \& de Silva, P. (2001). The development of a culturally sensitive symptom checklist for depression in Dubai. Transcultural Psychiatry, 38(2), 219-229.

Tang, A., Byrne, M., \& Qin, P. (2018). Psychological distress and risk for suicidal behavior among university students in contemporary China. Journal of Affective Disorders, 228, 101-108. 